(c) American Dairy Science Association, 2003.

\title{
Effect of Calcium and Water Injection on Structure-Function Relationships of Cheese ${ }^{1}$
}

\author{
A. J. Pastorino, N. P. Ricks, ${ }^{2}$ C. L. Hansen, and D. J. McMahon \\ Western Dairy Center \\ Department of Nutrition and Food Sciences \\ Utah State University, Logan 84322
}

\section{ABSTRACT}

Our objectives were to determine the effect of calcium and water injection on cheese structure and to relate changes in structure to changes in functional properties of cheese. Cheese with fat and moisture content similar to that of low-moisture part-skim Mozzarella was made according to a direct-acid, stirred/pressed-curd procedure. The cheese was then cut into blocks that were high-pressure-injected from one to five times, with either water or a $40 \%$ calcium chloride solution. Successive injections were performed $24 \mathrm{~h}$ apart. After 42 $\mathrm{d}$ of refrigerated storage, cheese microstructure and functionality were analyzed. When injected three or more times, water tended to increase cheese weight. The control, uninjected cheese, had the typical structure of a stirred/pressed-curd cheese: protein matrix interspersed with areas that originally contained fat and/or serum. Injecting water increased the area of cheese matrix occupied by protein, but it did not affect textural properties or melting of cheese. In contrast, when calcium was injected, a decrease in cheese weight was observed that was manifested through syneresis. The moisture content and $\mathrm{pH}$ of the cheese decreased as well. Calcium injection also decreased the area of cheese matrix occupied by protein. Cheese hardness increased, and cohesiveness and melting of cheese decreased upon calcium injection. We concluded that adding calcium to cheese alters how the proteins interact, which is manifested as changes in cheese microstructure. Such changes in cheese structure provide an understanding of changes in functional attributes of the cheese.

(Key words: Mozzarella, high-pressure injection, protein matrix, syneresis)

\section{INTRODUCTION}

Calcium content affects the rennet coagulation of milk. Calcium addition lowers the $\mathrm{pH}$ of milk by promot-

Received November 5, 2001.

Accepted May 10, 2002.

Corresponding author: D. J. McMahon; e-mail: djm@cc.usu.edu.

${ }^{1}$ Contribution number 7402 of the Utah Agricultural Experiment Station. Approved by the director.

${ }^{2}$ Current address: General Mills, 9000 Plymouth Ave. North, Minneapolis, MN 55427. ing exchange of $\mathrm{Ca}^{2+}$ for $\mathrm{H}^{+}$(Satia and Raadsveld, 1969; Jen and Ashworth, 1970), and it neutralizes negative charges in casein molecules (Green and Marshall, 1977) by reacting with phosphoserine residues and/or carboxylic acid groups of casein molecules (Dalgleish, 1983). As a result, the affinity of rennet for casein micelles is enhanced, and the rate of enzymatic reaction increases (Green and Marshall, 1977). Also, charge neutralization facilitates protein-to-protein interactions between casein molecules, which increases the aggregation of renneted micelles (Green and Marshall, 1977; Dalgleish, 1983). As a result of increased enzymatic action and aggregation of micelles, adding calcium to milk reduces the rennet coagulation time (Green and Marshall, 1977) and may increase gel strength if added in low concentration (Jen and Ashworth, 1970).

During cheesemaking, the $\mathrm{pH}$ at draining determines the retention of minerals, mainly calcium and phosphorous, in the cheese curd (Lawrence et al., 1983). The content of calcium then affects the extent and degree of protein aggregation determining the basic structure and texture of cheese (Lawrence et al., 1983). In cheeses with higher calcium content (higher cheese $\mathrm{pH}$ ), a high level of protein aggregation and bigger protein aggregates are observed, in comparison with cheeses with lower calcium content (lower cheese $\mathrm{pH}$ [Hall and Creamer, 1972]). These differences in protein aggregation determine the contrasting structure and texture of cheeses such as Swiss and Cheddar.

Calcium content also affects cheese functionality. According to Paulson et al. (1998a), increased calcium content resulted in decreased melting of nonfat Mozzarella cheese. Also, for any given $\mathrm{pH}$ value, there is a tendency for Cheddar cheese to become firmer as the calcium content of cheese increases (Lawrence et al., 1993)

The effect of calcium on cheesemaking parameters and cheese composition has been usually studied by adding a calcium source, such as calcium chloride, to milk during the early stages of cheesemaking (Satia and Raadsveld, 1969; Jen and Ashworth, 1970; Dalgleish, 1983; Solorza and Bell, 1998). However, changes in the calcium content of cheese are interdependent with 
changes in curd pH. According to Lawrence et al. (1993), the difficulty in conducting experiments on the chemical composition of cheese is that the variables of interest, especially $\mathrm{pH}$ and calcium content of cheese, are interdependent and influenced by a variety of parameters during cheesemaking. This makes it difficult to segregate the effect of $\mathrm{pH}$ per se from the effect of $\mathrm{pH}$-induced changes (Lucey and Fox, 1993). One way to overcome this difficulty is to change the calcium content of cheese by adding calcium after the cheese is manufactured. In this way, both the cheesemaking procedure and initial chemical composition of the cheese can be kept the same. Calcium could be added to the cheese after manufacture by injecting a concentrated solution at high pressure. High-pressure injection has been successfully used to inject fluids into cheese (Lee et al., 1978; Olson, 1979) and meat (Hendricks and Hansen, 1991).

Few studies have characterized changes in cheese structure as a result of changes in the chemical composition of cheese (Kiely et al., 1992; Tunick et al., 1993; Paulson et al., 1998b), and none has yet determined the effect of calcium content on cheese structure. Thus, limited data is available for determining relationships between the structure and functionality of Mozzarella cheese, on the basis of the chemical composition of cheese.

The objectives of the present research were to determine the effect of calcium and water injection on the structure of a cheese with similar fat and moisture content to that of low-moisture part-skim Mozzarella, and to relate changes in structure to changes in functional properties of the cheese.

\section{MATERIALS AND METHODS}

\section{Cheese Making}

Nine-kilogram blocks of cheese were made according to a direct-acid, stirred/pressed-curd procedure. Pasteurized, full-fat, nonhomogenized milk at $5^{\circ} \mathrm{C}$ was acidified by adding citric acid ( $1 \mathrm{~g} / \mathrm{kg}$ of milk) and sufficient acetic acid solution ( $10 \% \mathrm{wt} / \mathrm{wt}$ ) to lower the $\mathrm{pH}$ of milk to 5.4. The milk was then warmed to $33^{\circ} \mathrm{C}$ and $0.1 \mathrm{ml}$ of double-strength rennet (Chymax; Rhodia, Madison, WI) per kg of milk were added. After $15 \mathrm{~min}$, the curd was cut, allowed to heal for $5 \mathrm{~min}$, and cooked with stirring for $30 \mathrm{~min}$ at $33^{\circ} \mathrm{C}$. The whey was then drained and the cheese curd dry-salted (2\% wt/wt). After salting, the curd was placed into a $9-\mathrm{kg}$ cheese mold and pressed overnight. The cheese was then trimmed and cut into $0.3-$ to $0.4-\mathrm{kg}$ blocks that were vacuum-packaged and stored for $10 \mathrm{~d}$ at $4^{\circ} \mathrm{C}$, before the injection was performed.

\section{Cheese Injection}

A 2-stage homogenizer (Model 3DDL-3535; Crepaco, Chicago, IL) served as the pump for injection, and pressure on the homogenizer valve was set at $1400 \mathrm{psi}$. The burst duration was controlled via a solenoid-operated valve on the outlet line and set to $1 \mathrm{~s}$. Solutions flowed through a saffire nozzle $(0.02 \mathrm{~cm}$ in diameter $)$ and into the cheese. The cheese was high-pressure injected with either distilled water or a $40 \%$ (wt/wt) calcium chloride $\left(\mathrm{CaCl}_{2} \cdot 2 \mathrm{H}_{2} \mathrm{O}\right)$ solution $(4.2 \mathrm{M})$. Injections were performed using a $1 \times 1 \mathrm{~cm}$ injection pattern applied to one side of the cheese block $(5 \times 9 \mathrm{~cm})$ and then to the opposite side. On average, a total number of 64 injection sites were used for each block of cheese. The cheese block was then blotted with paper towels to remove extraneous fluid and vacuum packaged.

Successive injections were performed $24 \mathrm{~h}$ apart so that a series of cheeses was obtained that had been injected from one to five times. The cheeses were then stored at $4^{\circ} \mathrm{C}$ for $42 \mathrm{~d}$ to allow time for complete distribution of ions and moisture so that chemical equilibrium could be reached.

\section{Chemical Composition}

Fat content was determined using a modified Babcock method (Richardson, 1985), moisture content by using the vacuum-oven AOAC method 926.08 (1990), and calcium and sodium by inductively coupled plasmaatomic emission spectroscopy (US Environmental Protection Agency, 1992). A pH meter (model IQ240; IQ Scientific Instruments, Inc., San Diego, CA), with a stainless steel probe (model PH06-SS; IQ Scientific Instruments, Inc.), was used for determining cheese $\mathrm{pH}$, which was measured by taking a cheese sample from the cheese block and inserting the $\mathrm{pH}$ probe.

\section{Scanning Electron Microscopy}

The control, uninjected cheese, and cheese that had been injected five times with water or calcium solution were selected for examining cheese microstructure. Cheese samples, (approximately $1 \times 1 \times 10 \mathrm{~mm}$ ), were fixed in $2 \%$ glutaraldehyde solution for $1 \mathrm{~h}$ at room temperature $\left(22^{\circ} \mathrm{C}\right)$. The glutaraldehyde solution was then changed, and the samples were stored in new solution for $2 \mathrm{~d}$ at $4^{\circ} \mathrm{C}$. After refrigerated storage, the samples were processed according to McManus et al. (1993). Samples were frozen in liquefied Freon $22\left(-159^{\circ} \mathrm{C}\right.$; (Mallinckrodt Inc., Paris, KY), transferred to liquid nitrogen, cryofractured perpendicular to their long axis, and thawed in $2 \%$ glutaraldehyde solution. They were then dehydrated in a graded ethanol series followed by fat extraction with Freon 113 (Mallinckrodt Inc., Paris, 
KY). After overnight storage in Freon 113 at $4^{\circ} \mathrm{C}$, the samples were rehydrated by reversing the graded ethanol series, and washed with a $0.1 \mathrm{M}$ sodium cacodylate buffer (Electron Microscopy Sciences, Fort Washington, $\mathrm{PA}, \mathrm{pH}$ 7.2. The samples were then post-fixed for $2 \mathrm{~h}$ with a solution containing $1 \% \mathrm{OsO}_{4}$ (Electron Microscopy Sciences) and $1.5 \% \mathrm{~K}_{4} \mathrm{Fe}(\mathrm{CN})_{6} \cdot 3 \mathrm{H}_{2} \mathrm{O}$ (Fisher Scientific Co., Fair Lawn, NJ). This solution was replaced by a $2 \%$ tannic acid (Mallinckrodt Inc.) solution in cacodylate buffer, and the samples were left for $3 \mathrm{~h}$ at room temperature. The tannic acid solution was then replaced with the aforementioned solution of osmium tetroxide and potassium ferrocyanate, and samples left for $4 \mathrm{~h}$. This solution was later replaced with an aqueous solution of $1 \%$ hydroquinone (Mallinckrodt Inc.), and samples were left overnight. After the heavy metal impregnation, the samples were washed with distilled water, dehydrated in a graded ethanol series, and criticalpoint dried in a critical-point drier (Model 1200; Polaron, Waterford, United Kingdom) with $\mathrm{CO}_{2}$. Samples were viewed in a field emission scanning electron microscope (Model S-4000T FESEM; Hitachi Scientific Instruments, Mountain View, CA) operated at $3 \mathrm{kV}$. Images from each sample, at $1500 \times$ magnification, from two fields were recorded on Kodak TMX 120 film, and digitally using Spectrum 2.0 software (The Dindima Group Pty. Ltd., Ringwoood, Victoria, Australia). Fields were randomly selected from areas of the sample that exhibited planes of fracture of good quality.

\section{Image Analysis}

Digital images, with pixels in the grayscale from 0 to 255 (from black to white) were uploaded into Adobe Photoshop 4.0. The images were then converted from their grayscale values to binary images in which gray pixels were converted either to white or black pixels by applying the threshold function. In the original digital images, dark pixels corresponded to areas of the micrograph occupied by fat/serum pockets, whereas light pixels corresponded to areas occupied by protein matrix. Then, when thresholding, pixels having a gray value lower than the threshold level were converted to black pixels, while those having a gray value higher than the threshold level were converted to white pixels. However, because of the occurrence of superficial pockets and areas of protein matrix with pronounced fracture angles, some micrographs had under- and overestimated values of area occupied by fat/serum pockets when a single threshold level for all images was selected. To overcome this problem, a threshold level of either 60 or 70 was selected for each micrograph, depending on the individual image characteristics. Thus, a more precise differentiation between dark and light

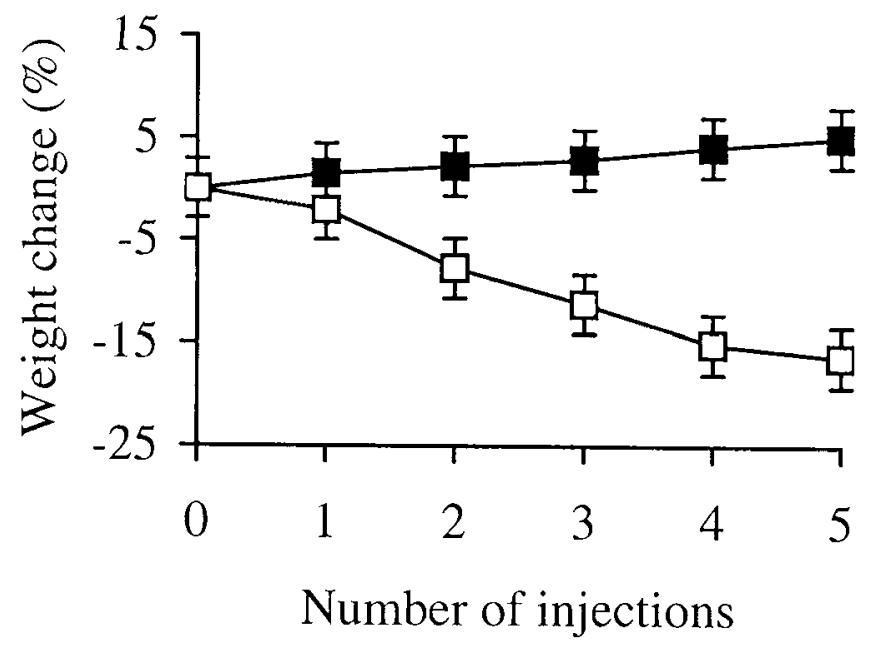

Figure 1. Weight of Mozzarella cheese blocks injected with either a calcium chloride solution $(40 \% \mathrm{w} / \mathrm{w}[\square])$ or water $(\boldsymbol{\square})$ and stored for $42 \mathrm{~d}$ at $4^{\circ} \mathrm{C}$. Successive injections performed $24 \mathrm{~h}$ apart. Error bar $=0.5 \times$ LSD.

areas was obtained, as determined by visually matching the original micrographs with their corresponding binary images. The proportions of dark and light pixels, and the areas occupied by them were then determined by applying the histogram function. Thus, the area of cheese matrix occupied by fat/serum pockets (dark areas) and protein matrix (light areas) was determined.

\section{Cheese Functionality}

Cheese weight was recorded before injection and after $42 \mathrm{~d}$ of storage at $4^{\circ} \mathrm{C}$. Also, after refrigerated storage, cheese functionalities, melting, and Texture Profile Analysis were analyzed. Melting was performed according to a modified tube test (Bongenrief and Olson, 1995). Duplicate cheese plugs, $15 \mathrm{~g}$ in weight, were cut from the cheese and placed into glass tubes, which were sealed with rubber stoppers and immersed in mineral oil $\left(90^{\circ} \mathrm{C}\right)$. The distance the cheese melted was then measured at $10 \mathrm{~min}$. Textile Profile Analysis was performed using a two-bite compression test run on a texture profile analyzer (Model 5542, Instron Corp., Canton, MA). The compression factor was $75 \%$, and the crosshead speed was set at $20 \mathrm{~mm} / \mathrm{min}$. Samples, 20 $\mathrm{mm}$ long by $16 \mathrm{~mm}$ in diameter, were taken from the cheese immediately after removal from the refrigerator and tested at approximately $5^{\circ} \mathrm{C}$. Hardness and cohesiveness were determined by analyzing the data according to Bourne (1978).

\section{Experimental Design and Statistical Analysis}

The experiment was conducted in triplicate as a randomized block design with cheesemaking day as the 
Table 1. Cheese composition.

\begin{tabular}{lcl}
\hline Variable & Mean & SEM \\
\hline Fat (\%) & 21.3 & 0.3 \\
Moisture (\%) & 50.2 & 1.4 \\
pH & 5.46 & 0.12 \\
Calcium (\%) & 0.28 & 0.01 \\
Sodium (\%) & 0.95 & 0.10 \\
\hline
\end{tabular}

block factor. Treatments were calcium and water injection, along with a control, uninjected cheese. Treatment levels were one to five, according to the number of injections performed on the cheese block. Two cheese samples were analyzed for each variable except weight. For scanning electron microscopy, two cheese samples from one replication were analyzed. Thus, each sample was considered as a replicate for analysis. Statistical analysis, ANOVA, was performed using SAS (1991). Individual comparisons, contrast or LSD, between calciuminjected, water-injected and control (uninjected cheeses) were also performed. Significance was declared at $P \leq 0.05$.

\section{RESULTS}

\section{Cheese Composition}

The moisture and fat content of the control, uninjected cheese (Table 1) was in agreement with the US specifications for low-moisture part-skim Mozzarella cheese. The calcium content was as expected, according to the cheesemaking procedure, whereas the sodium

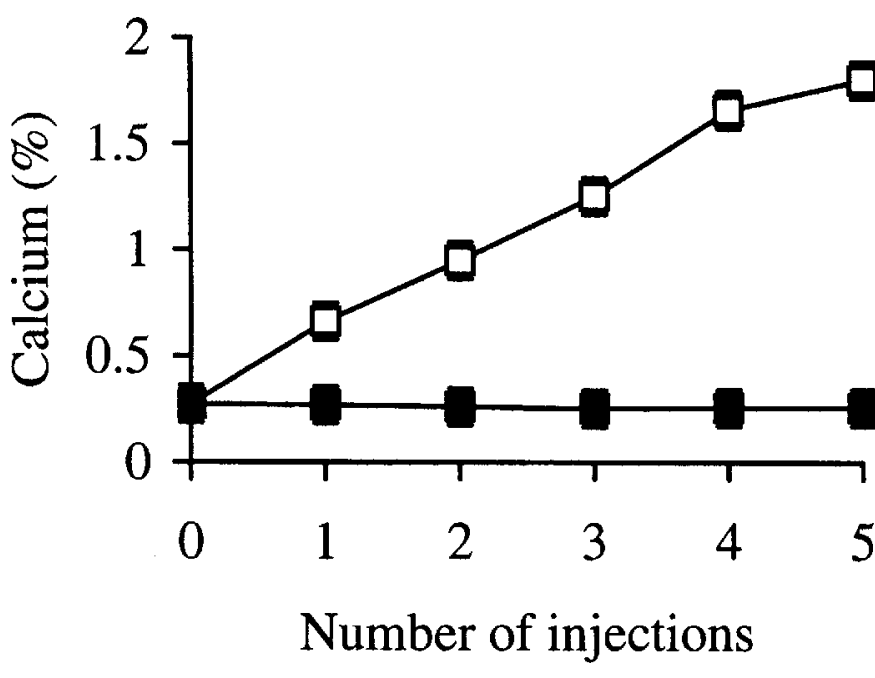

Figure 2. Calcium content of Mozzarella cheese injected with either a calcium chloride solution $(40 \% \mathrm{w} / \mathrm{w}[\square])$ or water (ם) and stored for $42 \mathrm{~d}$ at $4^{\circ} \mathrm{C}$. Successive injections performed $24 \mathrm{~h}$ apart. Error bar $=0.5 \times$ LSD. content was higher than expected (Table 1). Using the direct-acid cheesemaking procedure resulted in a cheese that had less than half the amount of calcium normally present in low-moisture part-skim Mozzarella cheese, $0.3 \%$ compared to $0.7 \%$ (Kosikowski and Mistry, 1997). Similar lower-calcium contents have been reported when making nonfat Mozzarella cheese with direct acidification of milk (Paulson et al., 1998a, 1998b).

Water and calcium injection affected the weight of cheese blocks (Table 2). Even though it was not significant, water injection tended to increase cheese weight. Part of the injected water was contained within the cheese block, and after five injections the weight of the cheese block had increased by $5 \%$ (Figure 1), with no serum released from the cheese during storage. In contrast, calcium injection significantly decreased the weight of cheese (Figure 1), and considerable serum was observed in the cheese package during storage (including overnight storage between successive injections). After each injection, the cheese had been blotted so the serum in the package was serum-expelled from the cheese, rather than residual injectant not incorporated into the cheese block.

Calcium content was unaffected by water injection (Table 2), and it remained at $0.3 \%$ (Figure 2). In contrast, calcium injection significantly increased the calcium content of cheese (Table 2). After five injections, the calcium content of the cheese was $1.8 \%$, compared with $0.3 \%$ in the control (Figure 2). Each calcium injection increased the calcium content of cheese another $0.3 \%$.

Even though water injection had no significant effect on the moisture content and $\mathrm{pH}$ of cheese $(P>0.05)$, injecting calcium significantly affected both (Table 2 ). Thus, the moisture content of cheese significantly decreased with calcium injection, from an initial 50\% down to $37 \%$ after five injections (Figure 3 ). This decrease in moisture content was associated with syneresis observed between successive calcium injections and during subsequent storage of the cheese. Also, a significant decrease in cheese $\mathrm{pH}$ occurred upon calcium injection (Table 2), from 5.5 to 4.6 after five injections (Figure 4).

\section{Cheese Microstructure}

The control, uninjected cheese, had a structure typical of a stirred/pressed-curd cheese, with protein matrix interspersed with areas that originally contained fat and/or serum (Figure 5a). In contrast, the water-injected cheese had fewer void spaces distributed throughout the protein matrix (Figure 5b). The structure of calcium-injected cheese was similar to that of the control cheese, although the void spaces appeared 
Table 2. Statistical results for the effect of adding calcium chloride (40\% w/w) and water on chemical and functional properties of Mozzarella cheese after $42 \mathrm{~d}$ of storage at $4^{\circ} \mathrm{C}$.

\begin{tabular}{lllll}
\hline & & \multicolumn{3}{c}{ Contrast } \\
\cline { 3 - 5 } Source/variable & Model $^{1}$ & $\begin{array}{l}\text { Uninjected } \\
\text { vs. Calcium }\end{array}$ & $\begin{array}{l}\text { Uninjected } \\
\text { vs. Water }\end{array}$ & $\begin{array}{l}\text { Calcium } \\
\text { vs. Water }\end{array}$ \\
\hline & $P<$ & $P<$ & $P<$ & $P<$ \\
Calcium & 0.001 & 0.001 & $\mathrm{NS}^{2}$ & 0.001 \\
Moisture & 0.001 & 0.001 & $\mathrm{NS}$ & 0.001 \\
pH & 0.001 & 0.001 & $\mathrm{NS}$ & 0.001 \\
Weight & 0.001 & 0.001 & $\mathrm{NS}$ & 0.001 \\
Cohesiveness & 0.01 & 0.001 & $\mathrm{NS}$ & 0.001 \\
Hardness & 0.05 & 0.01 & $\mathrm{NS}$ & 0.001 \\
Melting & 0.001 & 0.001 & $\mathrm{NS}$ & 0.001 \\
\hline
\end{tabular}

${ }^{1} \mathrm{Y}_{\mathrm{jkl}}=\mu+\mathrm{T}_{\mathrm{j}}+\mathrm{B}_{\mathrm{k}}+\mathrm{e}_{\mathrm{jk}}+\mathrm{d}_{\mathrm{jkl}}$, where $\mathrm{Y}$ is the variable of interest, $\mu$ is the overall mean, $\mathrm{T}$ is the treatment effect, $\mathrm{B}$ is the block effect, e is the error term, and $\mathrm{d}$ is the subsample effect.

${ }^{2}$ NS: not significant i.e., $P \geq 0.05$.

larger (Figure 5c). The binary images obtained when the threshold function was applied to the micrographs are shown in Figure 6. In these images, fat/serum pockets (black) were clearly differentiated from the protein matrix (white). For the control cheese (Figure 6a), the protein matrix occupied $81 \%$ of the cheese matrix, with fat/serum pockets occupying the remaining $19 \%$. Injecting water significantly increased the area of cheese matrix occupied by protein (Figure 6b). After five injections, the protein matrix occupied $92 \%$ of the cheese matrix area $(P<0.05)$. In contrast, injecting calcium significantly decreased the area of cheese matrix occupied by protein, from 81 to $69 \%(P<0.05)$ (Figure $6 \mathrm{c}$ ). Thus, when compared to the water-injected cheese, the protein matrix in calcium-injected cheese occupied $25 \%$ less of the micrograph area $(P<0.05)$.

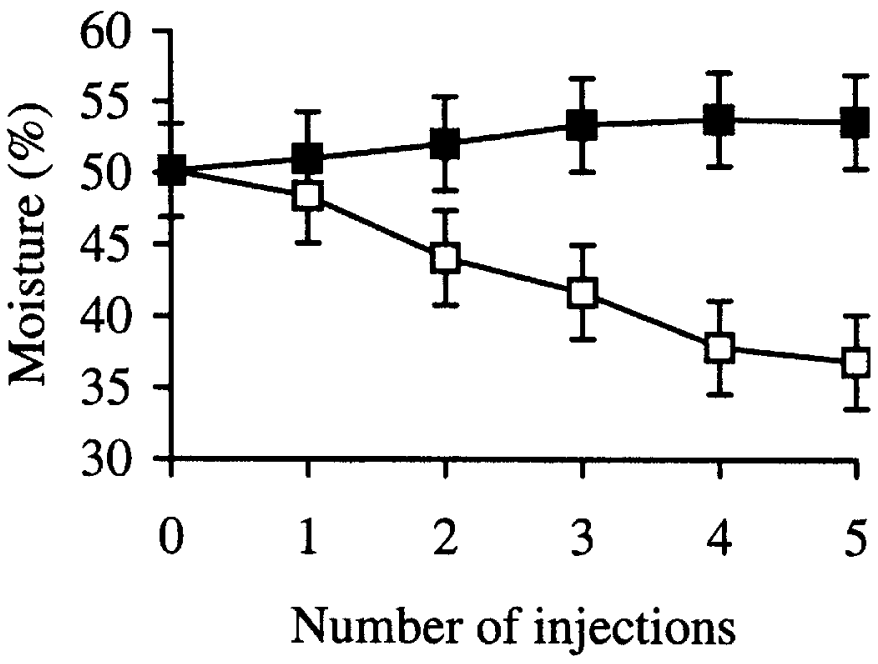

Figure 3. Moisture content of Mozzarella cheese injected with either a calcium chloride solution $(40 \% \mathrm{w} / \mathrm{w}[\square])$ or water $(\boldsymbol{\square})$ and stored for $42 \mathrm{~d}$ at $4^{\circ} \mathrm{C}$. Successive injections performed $24 \mathrm{~h}$ apart. Error bar $=0.5 \times \mathrm{LSD}$

\section{Cheese Functionality}

Water injection had no effect on textural or melting properties of cheese (Table 2). In contrast, injecting calcium into cheese affected both (Table 2). Thus, calcium injection significantly increased cheese hardness up until four injections (Figure 7) and significantly decreased both cheese cohesiveness and extent of melting (Figures 8 and 9, respectively). There was a large decrease in cheese cohesiveness and extent of melting after the first two calcium injections, with further injections causing little decrease.

\section{DISCUSSION}

\section{Chemical Composition}

Acidification of milk or casein micelle suspensions causes dissociation of calcium and other minerals such

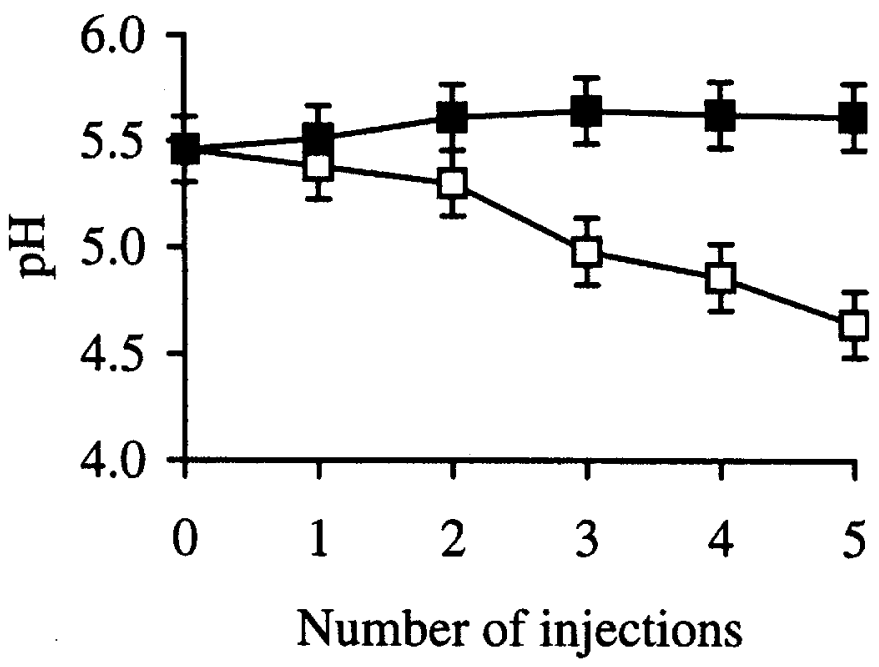

Figure 4. Mozzarella cheese $\mathrm{pH}$ after injection with either a calcium chloride solution $(40 \% \mathrm{w} / \mathrm{w}[\square])$ or water $(\square)$ and stored for 42 $\mathrm{d}$ at $4^{\circ} \mathrm{C}$. Successive injections performed $24 \mathrm{~h}$ apart. Error bar $=0.5$ $\times$ LSD. 

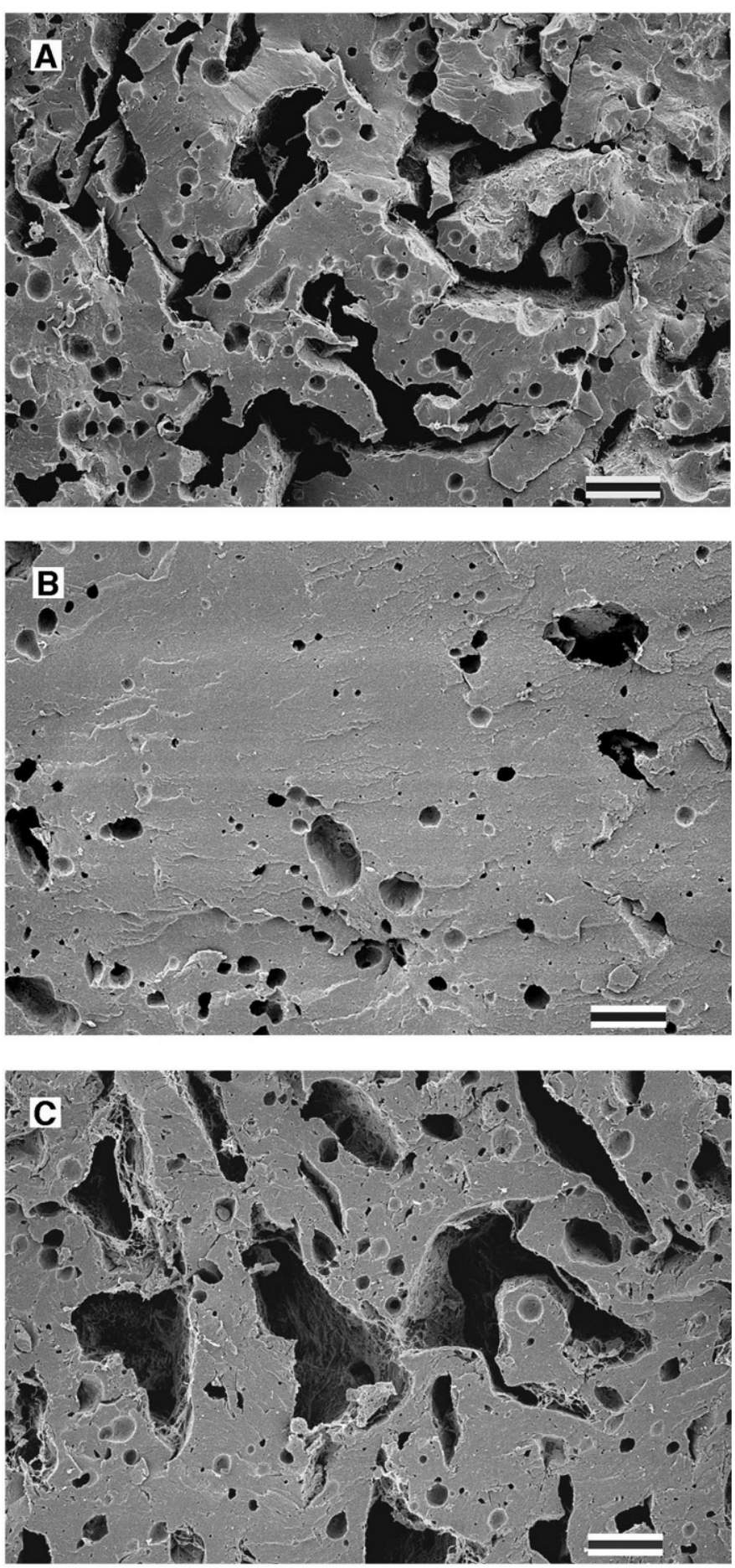

Figure 5. Scanning electron micrographs of Mozzarella cheese after $42 \mathrm{~d}$ of storage at $4^{\circ} \mathrm{C}$, a) uninjected cheese, b) water-injected cheese (5 injections), c) calcium-injected cheese (5 injections). Bar = $10 \mu \mathrm{m}$.
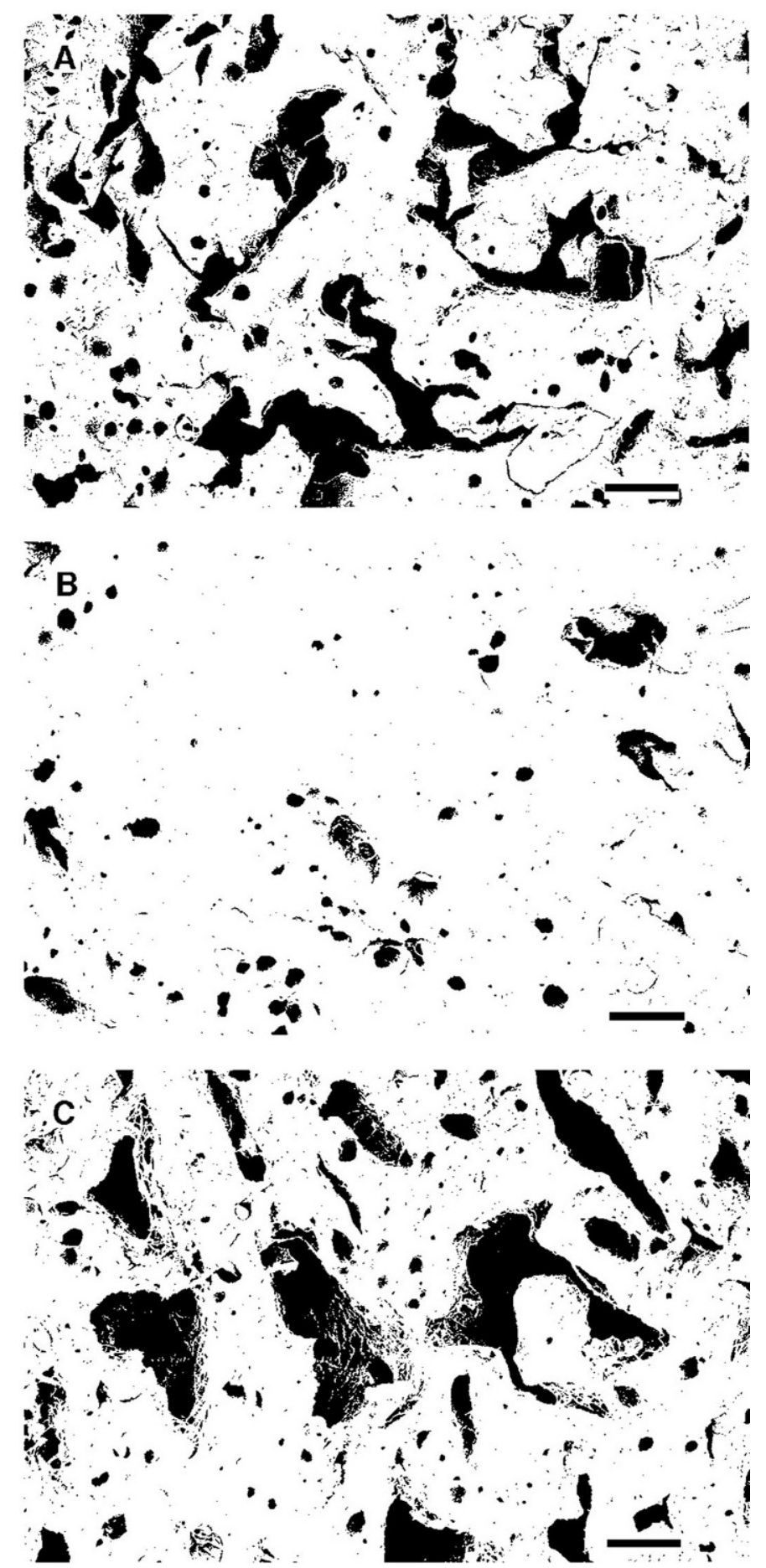

Figure 6. Binary image of scanning electron micrographs $5 \mathrm{a}, 5 \mathrm{~b}$, and $5 \mathrm{c}$ after thresholding. Bar $=10 \mu \mathrm{m}$. 


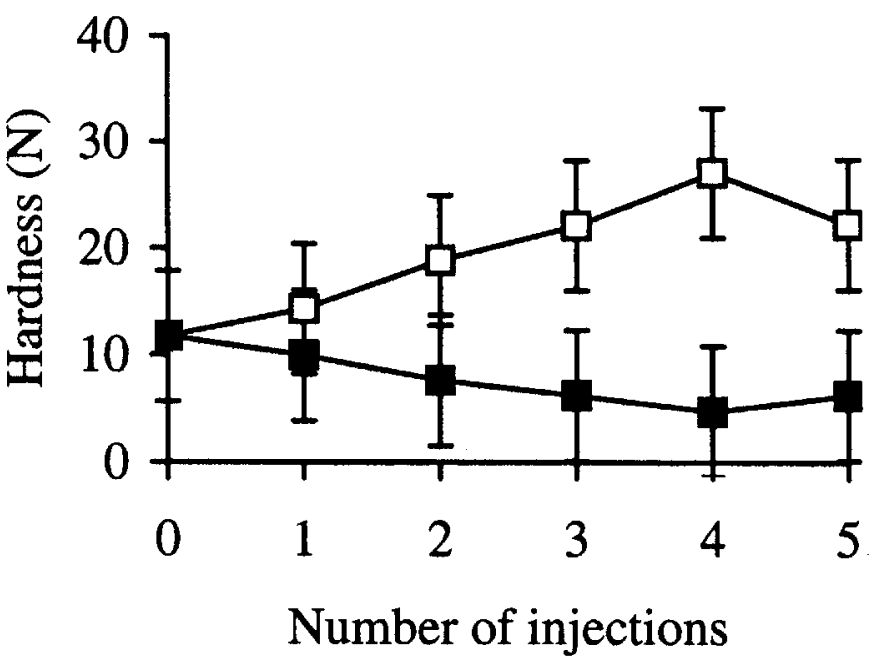

Figure 7. Hardness of Mozzarella cheese injected with either a calcium chloride solution $(40 \% \mathrm{w} / \mathrm{w}[\square])$ or water (ם) and stored for $42 \mathrm{~d}$ at $4^{\circ} \mathrm{C}$. Successive injections performed $24 \mathrm{~h}$ apart. Error bar $=$ $0.5 \times$ LSD.

as phosphorous and magnesium from the micelle and into the serum (Keller et al., 1974; Dalgleish and Law, 1989; Le Graët and Gaucheron, 1999). Consequently, cheese made by direct acidification of milk normally has lower calcium content (Shehata et al., 1967; Keller et al., 1974; Paulson et al., 1998a, 1998b) than cheese made by traditional procedures in which starter cultures are used to lower the $\mathrm{pH}$ of milk during cheesemaking. Thus, the lower calcium content of the uninjected cheese resulted from calcium solubilization

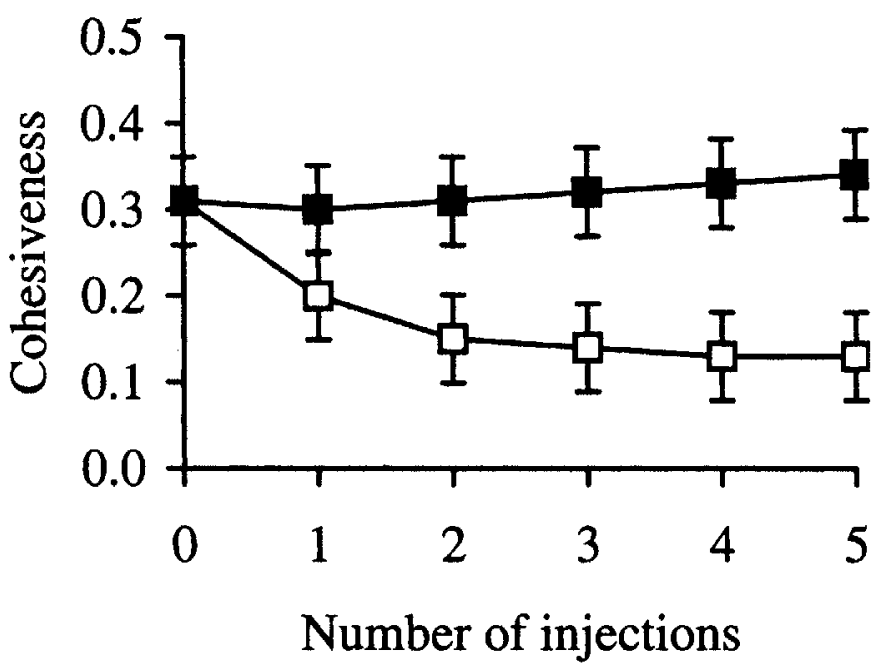

Figure 8. Cohesiveness of Mozzarella cheese injected with either a calcium chloride solution $(40 \% \mathrm{w} / \mathrm{w}[\square])$ or water $(\square)$ and stored for $42 \mathrm{~d}$ at $4^{\circ} \mathrm{C}$. Successive injections performed $24 \mathrm{~h}$ apart. Error bar $=0.5 \times$ LSD.

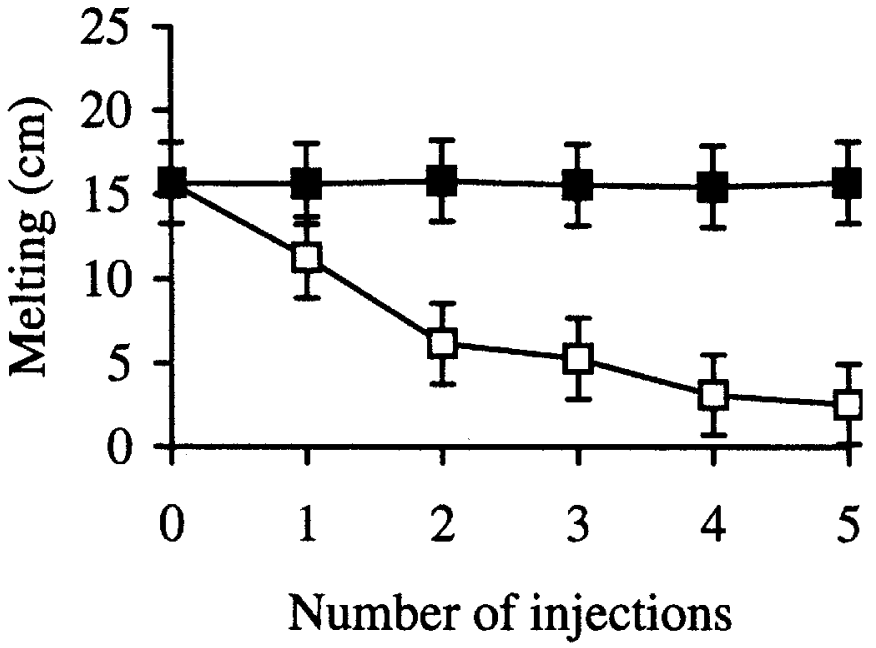

Figure 9. Melting of Mozzarella cheese injected with either a calcium chloride solution ( $40 \% \mathrm{w} / \mathrm{w}[\square]$ ) or water $(\boldsymbol{\square})$ and stored for $42 \mathrm{~d}$ at $4^{\circ} \mathrm{C}$. Successive injections performed $24 \mathrm{~h}$ apart. Error bar $=0.5 \times$ LSD.

brought about by the acidification of milk to $\mathrm{pH} 5.4$ prior to renneting. Also, fat retention may decrease when making cheese by direct acidification methods (Keller et al., 1974), as it was observed in the present experiment.

The syneresis that occurred after calcium injection indicates that adding calcium promoted protein-to-protein interactions within the cheese matrix, which resulted in decreased hydration of caseins and decreased capacity of the cheese to hold water present in pockets throughout the matrix. Calcium binds to casein molecules such as $\alpha_{\mathrm{s} 1}-\mathrm{CN}$ (Dalgleish and Parker, 1980) and $\beta$-CN (Parker and Dalgleish, 1981; Baumy et al., 1989), thus participating in the formation and aggregation of micelles in milk (Dalgleish and Parker, 1980; Gaucheron et al., 1997). Divalent cations such as calcium react with negatively charged groups in casein molecules, including phosphoserine residues (Baumy et al., 1989; Gaucheron et al., 1997) and possibly also carboxyl, phenolic, sulfhydryl, and imidazole groups (Gaucheron et al., 1997). As calcium binds to casein molecules and negative charges are neutralized, electrostatic repulsion between proteins decreases and protein-to-protein interactions involving hydrophobic regions are promoted (Gaucheron et al., 1997). Consequently, adding calcium to milk facilitates micelle aggregation (Green and Marshall, 1977; Dalgleish, 1983) and increases gel strength when added in levels lower that $10 \mathrm{mM}$ (Jen and Ashworth, 1970). Similarly, calcium injected into cheese seems to promote interactions between proteins within the cheese matrix, which then resulted in contraction of the protein matrix. 
The binding of calcium decreases the hydration of casein micelles (Green, 1982), whereas solubilization of micellar calcium can promote hydration of the paracasein in cheese (Kindstedt and Guo, 1997). Accordingly, calcium injection decreased protein solvation in the cheese. As protein-to-protein interactions increased, there was a concomitant contraction of the protein matrix and release of water from the matrix. As water molecules are released from the protein matrix they would initially accumulate in pockets distributed throughout the matrix. This can be described as microsyneresis, in which increased strength and number of interactions between proteins cause a contraction of the protein matrix and serum accumulates in the pockets distributed throughout the matrix. Expulsion of serum from the cheese block (macrosyneresis) would not be observed until the changes in the protein matrix become substantial enough to exert an actual shrinkage of the cheese block. Consequently, the loss of serum from within the cheese block caused decreased moisture content and weight of cheese.

In addition to its effect on moisture content, calcium injection decreased cheese $\mathrm{pH}$. When calcium is added to milk, calcium binding to casein promotes the release of protons that lowers the $\mathrm{pH}$ of milk (Satia and Raadsveld, 1969; Jen and Ashworth, 1970). Similarly, injecting calcium into cheese seems to promote an exchange of protons from casein that decreases the $\mathrm{pH}$ of cheese.

\section{Cheese Microstructure}

Lowering the calcium content of cheese by means of decreasing cheese $\mathrm{pH}$ can lead to decreased fusion of paracasein particles (Kiely et al., 1992) and increased hydration of the protein matrix (Kindstedt and Guo, 1997). As a result, the protein matrix swells (Kindstedt and Guo, 1997), and a more continuous three-dimensional network is observed in the cheese (Kiely et al., 1992). However, water injection promoted swelling of the protein matrix, even though the calcium content of the cheese was unaffected. Soluble calcium was not determined, but changes in its concentration are thought to help explain the rearrangement of the protein matrix observed upon water injection. In contrast, calcium injection caused a contraction of the protein matrix. Adding calcium promoted interactions between proteins, which would increase the fusion of paracasein particles and decrease the hydration of the protein matrix. Thus, the protein matrix contracted, and serum was released from within the matrix.

\section{Cheese Functionality}

As the calcium content of the cheese increased, serum was released from within the cheese matrix and the moisture content of cheese decreased. This would in turn decrease cheese cohesiveness. Tunick et al. (1991) reported such a decrease in cheese cohesiveness as the moisture content of low- (23\% average) and high-fat (46\% average) Mozzarella cheese decreased from 57 to $52 \%$ and from 52 to $47 \%$, respectively. Also, the lower $\mathrm{pH}$ of the cheese in calcium-injected cheese possibly affected cheese cohesiveness. A progressive dissociation of micelles into smaller aggregates occurs as the $\mathrm{pH}$ of cheese curd decreases (Hall and Creamer, 1972; de Jong, 1978; Roefs et al., 1985), and below pH 4.8 casein aggregates lose their identity, and cohesion is lost (Lawrence et al., 1987). Thus, decreased moisture content and $\mathrm{pH}$ would promote decreased cohesiveness of cheese upon calcium injection.

In addition to its effect on cohesiveness, calcium injection increased cheese hardness. Calcium binding to the protein matrix increases the rigidity of the cheese (Barbano, 1999). Thus, as calcium injection promoted protein-to-protein interactions, possibly through calcium bridging and charge neutralization, serum was expelled from within the protein matrix, and the cheese became firmer. Accordingly, in Cheddar cheese, for any given $\mathrm{pH}$ value there is a tendency for the cheese to become firmer as the calcium content of the cheese increases (Lawrence et al., 1993).

Calcium injection also affected cheese meltability, and in agreement with Paulson et al. (1998a), increased calcium content led to decreased melting of cheese. In their study, Paulson et al. (1998a) observed that increased calcium content of nonfat Mozzarella cheese, from 0.3 to $0.6 \%$, resulted in decreased melting. They also found cheese $\mathrm{pH}$ to have less effect than calcium content on cheese functionality. In fact, $\mathrm{pH}$ in the range of 5.8 to 5.3 had no effect on either the structure (data not published) or meltability of cheese when the calcium content of the cheese was kept the same $(0.6 \%)$. Thus, even though decreased cheese $\mathrm{pH}$ upon calcium injection possibly affected cheese structure and functionality, we think it played a secondary role compared with calcium content.

\section{CONCLUSIONS}

Increasing the calcium content of cheese alters how the proteins in the cheese matrix interact. It appears that calcium promotes protein-to-protein interactions, probably through calcium bridging and charge neutralization. Such increased and stronger interactions between proteins cause contraction of the protein matrix and expulsion of serum from the matrix. As the protein matrix becomes less hydrated, and protein-to-protein interactions are promoted, more energy must be applied to overcome these interactions and allow the proteins 
to flow when heated. Thus, cheese hardness increases and cohesiveness and meltability decrease when the calcium content of the cheese increases.

\section{ACKNOWLEDGMENTS}

This research was funded by Dairy Management Inc. (Rosemont, IL) and the Utah Agricultural Experiment Station.

\section{REFERENCES}

Association of Official Analytical Chemists (AOAC). 1990. Official Methods of Analysis. 15th ed. AOAC, Arlington, VA.

Barbano, D. M. 1999. Controlling functionality of Mozzarella cheese through process control. Pages 59-64 in Proc. Marschall Cheese Seminar. Rodhia Inc, Madison, WI.

Baumy, J. J., P. Guenot, S. Sinbandhit, and G. Brulé. 1989. Study of calcium binding to phosphoserine residues of $\beta$-casein and its phosphopeptide (1-25) by ${ }^{31} \mathrm{P}$ NMR. J. Dairy Res. 56:403-409.

Bongenrief, D. D., and N. F. Olson. 1995. Hydrolysis of $\beta$-casein increases Cheddar cheese meltability. Milchwissenschaft. $50: 678-682$.

Bourne, M. C. 1978. Texture profile analysis. Food Technol. 32:62-66.

Dalgleish, D. G. 1983. Coagulation of renneted bovine casein micelles: Dependence on temperature, calcium ion concentration and ionic strength. J. Dairy Res. 50:331-340.

Dalgleish, D. G., and J. R. Law. 1989. pH-induced dissociation of bovine casein micelles II. Mineral solubilization and its relation to casein release. J. Dairy Res. 56:727-735.

Dalgleish, D. G., and T. G. Parker. 1980. Binding of calcium ions to bovine $\alpha_{\mathrm{s} 1}$-casein and precipitability of the protein-calcium ion complexes. J. Dairy Res. 47:113-122.

De Jong, L. 1978. Proteolytic breakdown in soft cheese and its relation to consistency. The micellar structure of Meshanger cheese. Neth. Milk Dairy J. 32:15-25.

Gaucheron, F., Y. Le Graët, E. Boyabal, and M. Piot. 1997. Binding of cations to casein molecules: Importance of physicochemical conditions. Milchwissenschaft. 52:322-327.

Green, M. L. 1982. Effect on the composition and properties of casein micelles of interaction with ionic materials. J. Dairy Res. 49:87-98.

Green, M. L., and R. J. Marshall. 1977. The acceleration by cationic materials of the coagulation of casein micelles by rennet. J. Dairy Res. 44:521-531.

Hall, D. M., and L. K. Creamer. 1972. A study on the sub-microscopic structure of Cheddar, Cheshire, and Gouda cheese by electron microscopy. N. Z. J. Dairy Sci. Technol. 7:95-102.

Hendricks, D. G., and C. L. Hansen. 1991. Methods and compositions for tenderizing and upgrading the sensory qualities of red meat. US Pat. \# 5,053,237.

Jen, J. J., and U. S. Ashworth. 1970. Factors influencing the curd tension of rennet-coagulated milk. Salt balance. J. Dairy Sci. 53:1201-1206.

Keller, B., N. F. Olson, and T. Richardson. 1974. Mineral retention and rheological properties of Mozzarella cheese made by direct acidification. J. Dairy Sci. 57:174-180.

Kiely, L. J., P. S. Kindstedt, G. M. Hendricks, J. E. Levis, J. J. Yun, and D. M. Barbano. 1992. Effect of draw $\mathrm{pH}$ on the development of curd structure during the manufacture of Mozzarella cheese. Food Struct. 11:217-224.

Kindstedt, P. S., and M. R. Guo. 1997. Recent developments in the science and technology of pizza cheese. Aust. J. Dairy Technol. $52: 41-43$.
Kosikowski, F. V., and V. V. Mistry. 1997. Nutritional composition of cheeses, milk, fermented milks and whey powder. Page 690 in Cheese and Fermented Milk Foods. Vol. I, 3rd ed. F. V. Kosikowski and V. V. Mistry, ed. F. V. Kosikowski, L,L,C, Westport, CT.

Lawrence, R. C., L. K. Creamer, and J. Gilles. 1987. Symposium: Cheese repining technology. Texture development during cheese repining. J. Dairy Sci. 70:1748-1760.

Lawrence, R. C., J. Gilles, and L. K. Creamer. 1993. Cheddar cheese and related dry-salted cheese varieties. Chapter 1 in Cheese: Chemistry, Physics, and Microbiology. Vol. 2. P. F. Fox, ed. Chapman and Hall, London, UK.

Lawrence, R. C., J. Gilles, and L. K. Creamer. 1983. The relationship between cheese texture and flavour. N. Z. J. Dairy Sci. Technol. 18:175-190.

Lee, H. J., N. F. Olson, and D. B. Lund. 1978. High pressure injection of fluids into cheese. Process Biochem. 13:14-18.

Le Graët, Y., and F. Gaucheron. 1999. pH-induced solubilization of minerals from casein micelles: Influence of casein concentration and ionic strength. J. Dairy Res. 66:215-224.

Lucey, J. A., and P. F. Fox. 1993. Importance of calcium and phosphate in cheese manufacture: A review. J. Dairy Sci. 76:1714-1724.

McManus, W. R., D. J. McMahon, and C. J. Oberg. 1993. High resolution scanning electron microscopy of milk products: A new sample preparation procedure. Food Struct. 12:475-482.

Olson, N. F. 1979. Direct injection of salt in Mozzarella cheese. Pages 3-9 in Proc. First Biennial Marshal International Cheese Conference, Madison, WI.

Parker, T. G., and D. G. Dalgleish. 1981. Binding of calcium ions to bovine $\beta$-casein. J. Dairy Res. 48:71-76.

Paulson, B. M., D. J. McMahon, and C. J. Oberg. 1998a. Influence of $\mathrm{pH}$, calcium, and moisture on physical properties of nonfat Mozzarella cheese. 92nd Am. Dairy Sci. Assoc. Mtg. J. Dairy Sci. 81 (Supp. 1):13.

Paulson, B. M., D. J. McMahon, and C. J. Oberg. 1998b. Influence of sodium chloride on appearance, functionality, and protein arrangements in nonfat Mozzarella cheese. J. Dairy Sci. 81:2053-2064.

Richardson, G. H., ed. 1985. Page 351 in Standard Methods for the Examination of Dairy Products. 15th ed. Am. Publ. Health Assoc., Washington, DC.

Roefs, S. P. F. M., P. Walstra, D. G. Dalgleish, and D. S. Horne. 1985. Preliminary note on the change in casein micelles caused by acidification. Neth. Milk Dairy J. 39:119-122.

SAS User's Guide: Statistics, Version 6.1 Edition, 1991. SAS Inst., Inc., Cary, NC.

Satia, H. S., and C. W. Raadsveld. 1969. The quality of Gouda cheese, made from milk enriched with calcium and phosphate. Neth. Milk Dairy J. 23:276-286.

Shehata, A. E., M. Iyer, N. F. Olson, and T. Richardson. 1967. Effect of type of acid used in direct acidification procedures on moisture, firmness, and calcium levels of cheese. J. Dairy Sci. 50:824-827.

Solorza, F. J., and A. E. Bell. 1998. Effect of calcium on the minerals retention and cheesemaking parameters of milk. Int. J. Dairy Technol. 51:37-43.

Tunick, M. H., K. L. Mackey, J. J. Shield, P. W. Smith, P. Cooke, and E. L. Malin. 1993. Rheology and microstructure of low-fat Mozzarella cheese. Int. Dairy J. 3:649-662.

Tunick, M. H., K. L. Mackey, P. W. Smith, and V. H. Holsinger. 1991. Effects of composition and storage on the texture of Mozzarella cheese. Neth. Milk Dairy J. 45:117-125.

US Environmental Protection Agency. 1992. Method 6010a (Revision 1): Inductively coupled plasma-atomic emission spectroscopy. In Test Methods for Evaluating Solid Waste, Vol. 1A: Laboratory Manual Physical/Chemical Methods. Office of Solid Waste and Emergency Response. US Environ. Prot. Agency, Washington, DC. 